\title{
Os sacramentos como continuação dos atos de Cristo na Igreja
}

\author{
Orientador: Luiz Fernando Ribeiro Santana \\ Mestrando: Anderson Batista Monteiro \\ Área de Concentração: Teologia Sistemático-Pastoral \\ Linha de Pesquisa: Fé e Cultura
}

A partir do diálogo promovido pelo Movimento Litúrgico e pelo Concílio Vaticano II, entre a exegese, a patrística e a teologia dogmática, tem sido possível redescobrir um conceito mais bíblico, eclesial e profético dos sacramentos celebrados pela Igreja. Os sacramentos, à luz do pensamento conciliar, têm sido abordados pela teologia como atos do próprio Cristo, que se prolongam na vida de sua Igreja. O fio condutor de nossa pesquisa é a relação profunda que existe entre a teologia das ações simbólicas dos profetas e as de Jesus, as quais se prolongam nas celebrações litúrgicas da comunidade cristã e no testemunho vivencial dos batizados. Por meio dessas celebrações, os que creem são inseridos na vida do Ressuscitado e chamados a prolongar em suas vidas as palavras e ações de Cristo. Desse modo, os fiéis tomam consciência de exercerem o ministério profético que lhes foi confiado no batismo. A compreensão dos sacramentos como ações proféticas é capaz de revelar à própria Igreja a missão profética que é chamada a exercer no mundo de hoje, bem como a sua condição de sacramento de Cristo em prol da salvação de todos os homens.

Palavras-chave: Sagrada Escritura. Profetas. Sacramento. 